\title{
REASONS FOR GOING PUBLIC: THEORY VS. POLISH PRACTICE
}

\author{
Tomášs Meluzín ${ }^{1}$ \\ ${ }^{I}$ Vysoké učeni technické v Brně, Fakulta podnikatelská, Kolejní 2906/4, 61200 Brno \\ Email:meluzint@fbm.vutbr.cz
}

\begin{abstract}
The aim of this article is to identify the main reasons for the implementation of the IPO strategy according to the contemporary theory, and to compare it with practical approaches to this type of financing in companies that implemented the IPO in the Polish capital market. In agreement with the theoretical approaches, respondents from issuer companies mentioned the raising of external equity to be used to finance development investments as the main reason for the IPO implementation. The second most important reason for the IPO implementation is to use publicly traded shares for later acquisitions and mergers. Other important reasons for the IPO implementation include the increase of publicity and enhancement of the corporate image, increase in the company's attractiveness as an employer, and the determination of its market value. As far as disadvantages associated with the IPO are concerned, it follows from the results of our survey that respondents were mainly concerned about the time demands and the cost of the entire process when deciding whether to implement the IPO. Neither the fear of a loss or a curtailment of the control over the company, of the broadening of the shareholders' structure, nor the fear of strategic information leaks and its disuse by competitors gained any empirical support.
\end{abstract}

Keywords: financing, Initial Public Offering, IPO, Polish capital market, practical approaches, theoretical approaches.

JEL classification: G 32

Doručeno redakci: 9.9.2011; Recenzováno: 1.7.2012; 16.11.2012; 2.5.2013; Schváleno k publikování: 19.6.2013

\section{Introduction}

In recent years, raising capital to finance the development of companies through the Initial Public Offering (IPO) has become very important all over the world. The IPO is a situation in which a company offers its stock to the public for the first time, and at the same time, enters a public organized market in securities, represented most frequently by a stock market as its top institution. In developed capital markets, the IPO is among very important routes to raise the capital needed for business development. In the last decade, public stock offerings have also found their way to Central and Eastern European countries. There are, however, marked differences among them. While the Czech capital market has witnessed only seven IPOs in its modern history, there have been dozens of IPOs implemented every year in Poland over the past five years. Poland is thus the only capital market where quantitative research into IPOs can be conducted in the CEE region.

In 2010, the Faculty of Business and Management of Brno University of Technology (Czech Republic) conducted research in cooperation with the Faculty of Economics and Management of Nicolaus Copernicus University in Torun (Poland) with the aim of identifying the reasons that influenced Polish companies that had been considering to implement the IPO strategy, and to find out what importance issuer companies attributed to individual aspects that are mentioned in literature as disadvantages associated with IPO. Results of that research are presented in this paper.

\section{Theoretical Background}

Specialist literature offers many reasons why a company should enter the capital market through an IPO. All those reasons can be divided into three basic groups: 
- raising external equity for further growth of the company,

- securing benefits for existing shareholders,

- securing non-financial benefits from IPO implementation.

Discussing the main reasons for the IPO implementation, most authors, e.g. Chemmanur and Fulghieri (1999), Ritter and Welch (2002), Paleari et al. (2006), mention the raising of funds necessary for the company's expansion without restrictions associated with debt financing. The primary securities market offers an opportunity to raise capital from a large number previously unknown investors. As a result, more capital is accumulated that no single investor, or a limited number of investors, would be able or willing to provide. Public trading of stock gives a great advantage to both the issuers, to whom the stock issued provides longterm source of financing, and to the investors, who can sell the stock purchased practically at any time on secondary markets and thus to recover the desired liquidity, i.e. the money they invested. Short-term financial resources of individual investors are thus transformed into long-term resources, which then make it possible to implement large-scale development investments.

Raising funds through an IPO should be an alternative to borrowing, particularly in companies with high investments (now or in the foreseeable future), high proportion of debt in the capital structure, and high potential for growth. All of these factors, according to Panetta, Pagano and Zingales (1998), motivate companies to enter the capital market via an IPO.

Paleari et al. (2006) state that the initial public offering constitutes an extraordinary financial transaction by means of which the company can improve its liquidity and the capital structure. The balance sheet of those businesses that seek capital through public share offerings typically have a larger equity, that is a lower level of indebtedness. This reduces the likelihood of bankruptcy when operating at a loss (say in a period of economic recession).

In a general sense mentioned by, e.g., Pagano et al. (1993), Black and Gilson (1998), Meluzín and Zinecker (2009) another reason for the implementation of the IPO is to give an advantage to the existing shareholders, who, if their stock is publicly traded, will find it easier to sell their shares in the company on public capital markets. This allows the shareholders to be more flexible in their financial activities. At the same time, the payments made on this market have no effect on the financial situation of the issuing company. Raising the basic capital through a public issue also eliminates the difference between the large shareholders, who tend to take a long-term approach to investing, and the small ones, who value liquidity and are therefore inclined to take a short-term view of their investment. A frequent reason for an IPO is the majority shareholder's desire to reduce his stake in the company. In some cases, an IPO will resolve the problem of generational succession in a family-run enterprise. From the shareholder's perspective, the option to cash out his co-ownership by selling the shares of stock at any time on the secondary market is an advantage that imparts a great deal of flexibility to his financial decisions. The initial public offering can also be one of the methods for the withdrawal of venture capital funds from the company and way to realize profits on investments by a sale of the shares on the stock market. (Black and Gilson, 1998; Mello and Pardone, 1998).

The last reason, which is usually subordinate to the previously mentioned two, is to gain nonfinancial advantage from IPO implementation in the form of, e.g., higher interest of the 
media in publicly traded companies. (Maksimovic and Pichler, 2001; Ježek, 2004; Meluzín and Zinecker, 2009). The IPO is thus associated with positive effects in the area of marketing. A company that issues an IPO is usually motivated by a combination of several abovementioned reasons. The companies often choose this form of financing to raise the necessary capital and respond to the need of some existing shareholders (possibly the venture capitalists) who wish to liquidate their stake in the company through an IPO. (Meluzín et al., 2012)

Besides the above benefits, there are considerable costs and obligations associated with the IPO implementation that can generally be considered disadvantages of this form of financing. Some costs are directly associated with the process of taking the company public and listing it on a public securities market (stock exchange), such as the cost of the IPO process itself, or costs of regular disclosure of information about the company, other costs may be indirect in nature, and these may include, e.g., costs associated with underpricing (Paleari et al., 2006; Meluzín et al., 2012).

Public issue is also associated with non-financial disadvantages. Generally speaking, the company's operations will be scrutinized more closely and critically after it enters public capital markets. On one hand there will be the company's shareholders, whose different responses to the company's financial performance may affect the price of shares. On the other hand there will be undecided investors, analysts, banks, business partners, competitors and other entities monitoring the company's performance for various reasons, and comparing it with other companies in that sector. Ongoing requirement for regular disclosure of information is one of the conditions for public tradability. Yosha (1995) concluded that although the costs associated with the IPO implementation are appropriately high, the companies that are sensitive to information disclosure will often decide against implementing it specifically because of the obligation to regularly disclose information.

A company may choose to grow by buying other companies, but tables may turn and the company may find itself in the position of a company being bought, i.e. a company being acquired through a hostile takeover (Ježek et al., 2004). That situation can be blocked to some extent by issuing a limited number of shares through the initial public offering. In any case, the new shareholders will have an opportunity to participate in the company's management and the right to be informed about what's going on in the company. Table 1 shows the main advantages and disadvantages resulting from IPO implementation.

Table 1: Advantages and disadvantages of IPO implementation

\begin{tabular}{|c|c|}
\hline \multicolumn{2}{|c|}{ INITIAL PUbLIC OFFERING } \\
\hline AdVANTAGES & DISADVANTAGES \\
\hline $\begin{array}{l}\text { - raising external equity for further growth } \\
\text { of the company }\end{array}$ & $\begin{array}{l}\text { - } \begin{array}{l}\text { direct and indirect costs associated with } \\
\text { going public }\end{array} \\
\end{array}$ \\
\hline $\begin{array}{l}\text { - } \quad \text { capital structure optimization and } \\
\text { reduction the risk of over-indebtedness }\end{array}$ & $\begin{array}{l}\text { - } \quad \text { direct and indirect costs associated with } \\
\text { public tradeability of stocks }\end{array}$ \\
\hline $\begin{array}{l}\text { - increased bargaining power and credibility } \\
\text { in dealing with banks }\end{array}$ & - $\quad$ increased number of shareholders \\
\hline $\begin{array}{l}\text { - } \quad \text { recovering the desired liquidity of public } \\
\text { traded of stocks }\end{array}$ & - loss of decision-making autonomy \\
\hline $\begin{array}{l}\text { - } \quad \text { opportunity to address the problem of } \\
\text { generational replacement }\end{array}$ & - $\quad$ risk of leakage of strategic information \\
\hline $\begin{array}{l}\text { - } \quad \text { higher interest of the media in publicly } \\
\text { traded companies }\end{array}$ & $\begin{array}{l}\text { - } \quad \text { risk of being acquired through a hostile } \\
\text { takeover }\end{array}$ \\
\hline
\end{tabular}

Source: Meluzín and Zinecker (2009) 


\section{Material and methods}

To meet the research objective, an empirical research was made based on the collection of primary data using a questionnaire survey in companies that entered the main market of the Warsaw stock exchange through an IPO between the years 2007 and 2009. The reason for the time limits of the companies' entry onto capital markets through IPOs was to obtain relevant data from company representatives who recently personally participated in the IPO process. The respondent database compiled from the data published on the Internet pages of the Warsaw stock exchange and in the works published by Paleari et al. $(2008 ; 2009 ; 2010)$ was made up of 107 enterprises, or, rather, their chief financial officers or chairmen of the boards of directors.

The data was collected in two main stages. In early 2010, the questionnaire accompanied by a personalized and signed cover letter was sent to all companies on the survey list. To increase the return rate, the questionnaire was put into an electronic form and, in April 2010, sent by email to the individuals who had not replied the first time around, with a request for completion. We have received completed questionnaires from 21 companies, which corresponds to the response rate quota of $19.6 \%$.

\section{Research results}

In the first part of the text below, reasons for the companies' entry onto capital markets through the IPOs are given, and, in the second part, their managements' attitudes to disadvantages associated with this form of funding are presented.

\subsection{Reasons for the implementation of the IPO strategy}

Respondents were asked to indicate on a 5-point scale (1 - not important to 5 very important) how important the reasons given below were for their company's owner/management in their decisions about the IPO implementation.

The results are given in Table 2. The table gives statistical characteristics such as the mean, mode, mode frequency and standard deviation. The data indicate the relative frequency of respondents who did not consider the given reason important (i.e. used score points 1 or 2 ), had a neutral attitude towards it (i.e. used score point 3), or considered it important (i.e. used score points 4 or 5 ).

It follows from our research that almost all of the companies surveyed gave the raising of external equity for investments into development as the main reason for their implementation of the IPO (the mean importance of the reason $=4.86$; relative frequency of respondents expressing agreement with the evaluation $=95.24 \%$ ). The second most important reason why companies enter the capital market was the use of publicly traded shares for later acquisitions and mergers $(3.81 ; 76.19 \%)$. Other important reasons for IPO implementation include the strengthening of negotiating position in dealing with external equity providers $(3.71 ; 66.67 \%)$. attracting publicity and enhancing corporate image $(4.00 ; 66.67 \%)$, increase in the company's attractiveness as an employer, and the determination of its market value $(3.71 ; 61.91 \%)$.

Reducing the cost of capital was considered less important by $38.10 \%$ respondents, and the same percentage of respondents considered that reason as important. The diversification of the asset portfolio of the company's existing shareholders was among the less important reasons $(2.76 ; 47.62 \%)$ in the companies surveyed. Among reasons unimportant for the IPO implementation mentioned by the respondents there were the reduction of the company's 
debt $(2.38 ; 61.90 \%)$, withdrawal of venture capital from the company $(1.95 ; 80.95 \%)$ and addressing the issue of succession (1.38; $90.48 \%)$.

Table 2: Research results - Reasons for the implementation of IPO strategy

\begin{tabular}{|l|c|c|c|c||c|c|c|}
\hline \multirow{2}{*}{\begin{tabular}{c}
\multicolumn{1}{|c}{$\begin{array}{c}\text { Reason to implement } \\
\text { an IPO }\end{array}$} \\
\cline { 2 - 8 }
\end{tabular}} & \multicolumn{7}{c|}{ RESPONDENTS' ANSWERS } \\
\cline { 2 - 8 } & Average & Mode & $\begin{array}{c}\text { Mode } \\
\text { Frequency }\end{array}$ & $\begin{array}{c}\text { Standard } \\
\text { Deviation }\end{array}$ & $\begin{array}{c}\text { \% } \\
\text { 1-2 }\end{array}$ & $\begin{array}{c}\text { \% } \\
\mathbf{3}\end{array}$ & $\mathbf{4 - 5}$ \\
\hline \hline $\begin{array}{l}\text { Obtaining external equity for } \\
\text { developmental investments }\end{array}$ & 4.86 & 5.00 & 19 & 0.48 & 0.00 & 4.76 & 95.24 \\
\hline $\begin{array}{l}\text { Reducing the company's } \\
\text { indebtedness }\end{array}$ & 2.38 & 1.00 & 7 & 1.40 & 61.90 & 19.05 & 19.05 \\
\hline $\begin{array}{l}\text { Stronger bargaining position } \\
\text { with external capital providers }\end{array}$ & 3.71 & 4.00 & 9 & 1.10 & 14.29 & 19.04 & 66.67 \\
\hline Reducing the cost of capital & 3.05 & 2.00 & 6 & 1.24 & 38.10 & 23.80 & 38.10 \\
\hline $\begin{array}{l}\text { Diversifying the asset portfolio } \\
\text { of existing shareholders }\end{array}$ & 2.76 & 1.00 & 5 & 1.41 & 47.62 & 19.05 & 33.33 \\
\hline $\begin{array}{l}\text { Withdrawal of venture capital } \\
\text { from the company }\end{array}$ & 1.95 & 1.00 & 13 & 1.56 & 80.95 & 0.00 & 19.05 \\
\hline $\begin{array}{l}\text { Solving a problem of } \\
\text { succession }\end{array}$ & 1.38 & 1.00 & 15 & 0.67 & 90.48 & 9.52 & 0.00 \\
\hline $\begin{array}{l}\text { Publicity and company image } \\
\text { enhancement }\end{array}$ & 4.00 & 5.00 & 9 & 1.10 & 4.76 & 28.57 & 66.67 \\
\hline
\end{tabular}

Source: own compilation

\subsection{Disadvantages associated with the IPO}

Respondents were also asked to indicate on a 5-point scale (1 - no influence to 5 very strong influence) to what extent individual disadvantages influenced their company's owners/management decisions regarding the IPO implementation.

The results are presented in Table 3 . The table gives statistical characteristics such as the mean, mode, mode frequency and standard deviation. The data indicate the relative frequency of respondents who were not influenced in their IPO implementation decision by the given factor (i.e. used score points 1 or 2), were somewhat influenced by it (i.e. used score point 3 ), or were strongly influenced by it (i.e. used score points 4 or 5).

In this part of research, results were not as clear cut as in the previous part. The respondents stated that in their deliberations about the use of IPO strategy they were mostly concerned about the time demands and the costs associated with the process (the mean importance of the factor $=3.24$ and 3.14, respectively; relative frequency of respondents expressing agreement with the evaluation $=52.38 \%$ and $42.86 \%$, respectively). The factors that influenced their decision about the IPO implementation to a lesser extent included the regular information disclosure requirement $(3.29 ; 47.62 \%)$, providing for company transparency $(3.10 ; 42.86 \%)$ and the fear of IPO failure $(3.00 ; 38.10 \%)$.

The rest of the factors, although frequently mentioned in literature as major disadvantages for companies entering capital markets, had only little influence on the surveyed companies' decisions regarding the IPO implementation. They are mainly the fear of a loss or a curtailment of the control over the company $(2.62 ; 61.90 \%)$, broadening of the shareholders' structure $(2.33 ; 61.90 \%)$ and the fear of strategic information leaks and misuse of the information by competitors $(2.86 ; 47.62 \%)$. 
Table 3: Research results - Influence of IPO disadvantages on its implementation

\begin{tabular}{|l|c|c|c|c||c|c|c|}
\hline \multirow{2}{*}{ IPO Disadvantages } & \multicolumn{7}{|c|}{ RESPONDENTS' ANSWERS } \\
\cline { 2 - 8 } & Average & Mode & $\begin{array}{c}\text { Mode } \\
\text { Frequency }\end{array}$ & $\begin{array}{c}\text { Standard } \\
\text { deviation }\end{array}$ & $\begin{array}{c}\text { \% } \\
\mathbf{1}-\mathbf{2}\end{array}$ & $\begin{array}{c}\text { \% } \\
\mathbf{3}\end{array}$ & $\mathbf{4}-\mathbf{5}$ \\
\hline \hline $\begin{array}{l}\text { Costs associated with an } \\
\text { IPO }\end{array}$ & 3.14 & 4.00 & 7 & 1.15 & 28.57 & 28.57 & $\mathbf{4 2 . 8 6}$ \\
\hline $\begin{array}{l}\text { Compliance with the } \\
\text { periodic reporting duty }\end{array}$ & 3.29 & 3.00 & 10 & 0.96 & 19.05 & $\mathbf{4 7 . 6 2}$ & 33.33 \\
\hline $\begin{array}{l}\text { Ensuring corporate } \\
\text { transparency }\end{array}$ & 3.10 & 3.00 & 9 & 0.94 & 23.81 & $\mathbf{4 2 . 8 6}$ & 33.33 \\
\hline $\begin{array}{l}\text { Fear of limitation or loss of } \\
\text { company control }\end{array}$ & 2.62 & 2.00 & 10 & 1.32 & $\mathbf{6 1 . 9 0}$ & 19.05 & 19.05 \\
\hline Fear of IPO failure & 3.00 & 3.00 & 8 & 0.89 & 33.33 & $\mathbf{3 8 . 1 0}$ & 28.57 \\
\hline $\begin{array}{l}\text { Time-consuming aspect of } \\
\text { the IPO }\end{array}$ & 3.24 & 4.00 & 8 & 1.30 & 28.57 & 19.05 & $\mathbf{5 2 . 3 8}$ \\
\hline $\begin{array}{l}\text { Expansion of the } \\
\text { shareholder structure }\end{array}$ & 2.33 & 2.00 & 12 & 0.58 & $\mathbf{6 1 . 9 0}$ & 38.10 & 0.00 \\
\hline $\begin{array}{l}\text { Fear of strategic } \\
\text { information leakage and its } \\
\text { misuse by competition }\end{array}$ & 2.86 & 2.00 & 10 & 1.01 & $\mathbf{4 7 . 6 2}$ & 28.57 & 23.81 \\
\hline
\end{tabular}

Source: own compilation

\section{Conclusion}

The results of this survey indicate that the academic and theoretical approaches to the IPO process are, in the conditions of the Polish capital market, generally applicable. However, the respondents' observations also suggest that there is a need for additional information that would complement and refine the existing theoretical models of IPOs. In agreement with the theoretical approaches, respondents from issuer companies mentioned the raising of equity to be used to finance development investments as the main reason for IPO implementation. The second most important reason for the IPO implementation is to use publicly traded shares for later acquisitions and mergers. The degree of importance of this reason is surprising in view of the limited interest given to this aspect by the theory. The newly issued shares can make it possible for the company that implements the IPO strategy to become either the acquirer or the target, particularly in transactions financed through shares. Other important reasons for the IPO implementation include the increase of publicity and enhancement of the corporate image, increase in the company's attractiveness as an employer, and the determination of its market value. Issuer companies do not generally perceive the IPO as an instrument of the company's direct debt reduction but, rather, as a means of strengthening its position when negotiating with any future providers of external equity capital. Survey results indicate that the withdrawal of venture capital fund from the company is not among important reasons for the IPO implementation in the conditions of the Polish capital market. The respondents adopted the same attitude to the issue of succession. As far as disadvantages associated with the IPO are concerned, it follows from the results of our survey that respondents were mainly concerned about the time demands and the cost of the entire process when deciding whether to implement the IPO. The factors that influenced their decision about the IPO implementation to a lesser extent included the regular information disclosure requirement, providing for company transparency and the fear of the IPO failure. It was interesting to note that many of the factors that are often presented as the IPO disadvantages did not significantly affect decision-making processes in the IPO-planning companies surveyed. Neither the fear of a loss or a curtailment of the control over the company, of the broadening of the shareholders' structure, nor the fear of strategic information leaks and its disuse by competitors gained any 
empirical support. A comparison of the theoretical approaches with the survey results demonstrates that the theoretical model of the IPO process is, in principle, applicable to the conditions in the Polish capital market, while at the same time highlighting the existence of certain differences. The results of this survey made it possible to formulate new insights as contributions towards a better understanding of corporate financing strategies, particularly under the specific conditions of the CEE region.

\section{Acknowledgement}

The paper was written with the financial support of the Czech Science Foundation (Grant Agency of the Czech Republic), grant project No. 13-38047S "IPO Strategy - Specific Approaches in the CEE Region".

\section{References}

[1] BLACK, B. S. and R. J. GILSON, 1998. Venture capital and the structure of capital markets: Banks versus stock markets. Journal of Financial Economics, 47, 243-277. ISSN 0304-405X.

[2] CHEMMANUR, T. J. and P. A. FULGHIERY, 1999. Theory of the Going-Public Decision. Review of Financial Studies, 12(2), 249-279.

[3] JEŽEK, T. a kol., 2004. Jak emitovat akcie a dluhopisy na kapitálovém trhu. Praha: KCP, 80 s. ISBN 80-239-2193-2.

[4] MAKSIMOVIC, V. and P. PICHLER, 2001. Technological innovation and initial public offerings. Review of Financial Studies, 14, 459-494. ISSN 0893-9454.

[5] MELLO, A. S. and J. E. PARDONE, 1998. Going Public and the Ownership Structure of the Firm. Journal of Financial Economics, 49, 79-109.

[6] MELUZÍN, T. a M. ZINECKER, 2009. IPO - Prvotní veřejná nabidka akcií jako zdroj financování rozvoje podniku. Brno: Computer Press, 188 s. ISBN 978-80-251-2620-2.

[7] MELUZÍN, T., M. ZINECKER a J. LAPINSKA, 2012. Initial Public Offering: Theory and Practice of Czech and Polish Companies. Toruň: Polish Economic Society - Branch in Torun, 179 s. ISBN 978-83-62049-15-8.

[8] PAGANO, M., F. PANETTA a L. ZINGALES, 1998. Why do companies go public: An empirical analysis. Journal of Finance, 53, 27-64.

[9] PALEARI, S. et al., 2006. Academic EurIPO Fact Book 2006. Bergamo: Universoft, 137 s. ISBN 1-4196-4673-7.

[10] PALEARI, S. et al., 2008. Academic EurIPO Fact Book 2008. Bergamo: Universoft, 179 s. ISBN 978-1-4392-1510-4.

[11] PALEARI, S. et al., 2009. Academic EurIPO Fact Book 2009. Bergamo: Universoft, 187 s. ISBN 978-1-4392-3566-9.

[12] PALEARI, S. et al., 2010. Academic EurIPO Fact Book 2010. Bergamo: Universoft, 153 s. ISBN 978-1-4515-7162-2.

[13] RITTER, J. R. and I. WELCH, 2002. A review of IPO activity, pricing, and allocations. Journal of Finance, 57(4), 1795-1828. ISSN 0022-1082.

[14] YOSHA, O., 1995. Information Disclosure Costs and the Choice of Financing Source. Journal of Financial Intermediation, 4(1), 3-20. ISSN 1042-9573. 